\title{
Peningkatan Keterampilan dan Perekonomian Masyarakat Pesisir Pulau Lemukutan melalui Pelatihan Pembuatan Snack Berbasis Rumput Laut
}

\author{
Warsidah $^{1}$, Ikha Safitri ${ }^{1 *}$, Mega Sari Juane Sofiana ${ }^{1}$, Sukal Minsas ${ }^{1}$, Agus Yuliono ${ }^{2}$ \\ ${ }^{1}$ Jurusan Ilmu Kelautan, FMIPA, Universitas Tanjungpura \\ ${ }^{2}$ Program Studi Antropologi Sosial, FISIP, Universitas Tanjungpura \\ Korespondensi: isafitri@marine.untan.ac.id
}

\begin{abstract}
The waters of Lemukutan Island have the potential of natural resources, including seaweed. Since 2011, Lemukutan Island has been the largest seaweed cultivation center in West Kalimantan. However, the Covid-19 pandemic has attacked all sectors and caused a decline in prices for fishery-based food commodities. This condition causes the farmers to suffer losses and the seaweed cultivation activity also decreases. Training on making snacks and seaweed jelly boba has been carried out to revive the economy of the coastal communities of Lemukutan Island. This activity involves all levels of the community through representatives of each $R T$ using a hybrid method. Training is carried out with strict health protocols. This activity aims to improve the skills of coastal communities in processing seaweed-based foods. The training participants were very enthusiastic, from the presentation about the benefits of consuming seaweed for human health to the practice of making seaweed snacks and jelly.
\end{abstract}

Keywords: food diversification; Covid-19 pandemic; seaweed; snack; jelly

\begin{abstract}
Abstrak
Perairan Pulau Lemukutan memiliki potensi sumber daya alam yang melimpah termasuk rumput laut. Sejak 2011, Pulau Lemukutan menjadi sentra usaha budi daya rumput laut terbesar di Kalimantan Barat. Namun, pandemi Covid-19 telah menyerang semua sektor kehidupan dan menyebabkan kemerosotan harga pada komoditas pangan berbasis perikanan. Kondisi ini mengakibatkan pembudi daya mengalami kerugian dan usaha budi daya rumput laut di Pulau Lemukutan juga menurun. Pelatihan pembuatan snack krenyes dan jelly boba rumput laut telah dilaksanakan untuk menumbuhkan kembali perekonomian masyarakat pesisir Pulau Lemukutan. Kegiatan ini melibatkan seluruh lapisan masyarakat Pulau Lemukutan melalui perwakilan tiap RT dengan metode hibrid. Pelatihan dilaksanakan dengan protokol kesehatan yang tegas. Kegiatan ini bertujuan untuk meningkatkan keterampilan masyarakat pesisir dalam mengolah makanan berbasis rumput laut. Peserta pelatihan sangat antusias mengikuti kegiatan, mulai dari pemaparan materi tentang manfaat dari mengonsumsi rumput laut bagi kesehatan manusia hingga praktik pembuatan snack dan jelly rumput laut.
\end{abstract}

Kata kunci: diversifikasi pangan; pandemi Covid-19; rumput laut; snack; jelly 


\section{Pendahuluan}

Pulau Lemukutan terletak di Kabupaten Bengkayang, Kalimantan Barat dan merupakan pulau terbesar berpenduduk dengan luas wilayah 1.235 ha (BPS Kabupaten Bangkayang, 2019). Perairan Pulau Lemukutan memiliki potensi sumber daya alam yang melimpah termasuk rumput laut (Sofiana et al., 2018). Jenis rumput laut yang banyak ditemui adalah Eucheuma sp., Caulerpa sp., dan Sargassum sp. (Dermawan et al., 2014). Pulau Lemukutan merupakan sentra budi daya rumput laut Eucheuma cottoni dan E. spinosum. Spesies tersebut masuk dalam golongan rumput laut merah yang secara ekonomi sangat berpotensi sebagai komoditas unggulan perairan laut Kalimantan Barat. Eucheuma merupakan sumber utama karagenan dan menyumbang lebih dari 80\% produksi karagenan dunia (Pereira and Yarish, 2008; Hayashi et al., 2010). Kandungan karagenan yang tinggi membuat jenis rumput laut ini banyak dipasarkan, baik domestik maupun mancanegara.

Pandemi Covid-19 yang terjadi sepanjang tahun 2020 hingga saat ini menjadi ancaman yang serius dan berdampak global pada semua sektor kehidupan. Pertumbuhan ekonomi Indonesia mengalami penurunan dari 5,02\% pada triwulan I tahun 2019 menjadi 2,8\% pada triwulan I tahun 2020 (BPS, 2020). Pemberlakuan pembatasan sosial berskala besar telah melumpuhkan seluruh sendi kehidupan dalam masyarakat, termasuk pembudi daya rumput laut di wilayah pesisir Pulau Lemukutan. Kelumpuhan di berbagai sektor secara nyata menyebabkan banyak masyarakat kehilangan pekerjaan sebagai sumber pendapatan dan menurunnya daya beli. Selain itu, kondisi ini membuat produksi komoditas perikanan dan pertanian semakin menurun serta sulit untuk dipasarkan.

Di tingkat pengepul, harga rumput laut E. cottonii menurun drastis dari Rp12.500,00 menjadi Rp2.500,00 per kilogram berat kering. Para pembudi daya mengalami kerugian besar karena kesulitan memasarkan hasil panen dan nilai jual lebih rendah daripada biaya operasional selama proses budi daya. Kondisi ini membuat pembudi daya enggan untuk melanjutkan kegiatannya. Oleh karena itu, tim dosen Jurusan Ilmu Kelautan, Fakultas Matematika dan Ilmu Pengetahuan Alam, Universitas Tanjungpura melakukan kegiatan Pengabdian Kepada Masyarakat (PKM) sebagai usaha untuk menumbuhkan kembali perekonomian masyarakat pesisir Pulau Lemukutan melalui pelatihan pembuatan snack krenyes dan jelly boba dari rumput laut $E$. cottonii. Tujuan dari pelatihan ini ialah dapat meningkatkan keterampilan masyarakat pesisir Pulau Lemukutan dalam mengolah makanan berbasis rumput laut. Adanya diversifikasi produk olahan diharapkan dapat memberikan nilai tambah (added value) dan meningkatkan harga jual produk.

\section{Pendekatan Pelaksanaan Program}

Rangkaian pelaksanaan PKM yang berjudul "Peningkatan Keterampilan dan Perekonomian Masyarakat Pesisir Pulau Lemukutan Kalimantan Barat melalui Pelatihan Pembuatan Snack berbasis Rumput Laut" dilaksanakan secara bybrid antara online (daring) dan offline (luring). Pelatihan dilakukan dengan mengundang perwakilan warga tiap RT di Desa Lemukutan, pelaksanaannya dilakukan dalam dua tahap yaitu dengan metode ceramah dan dilanjutkan demonstrasi pembuatan snack krenyes dan jelly boba. Dari perwakilan RT yang hadir diharapkan dapat menjadi kader-kader PKM 
untuk menyosialisasikan kepada anggota masyarakat di RT masing-masing sehingga dapat meningkatkan kembali aktivitas perekonomian di pulau tersebut.

Kegiatan dihadiri oleh 50 orang yang terdiri atas 40 orang peserta remaja dan ibu-ibu perwakilan 6 RT yang ada di Desa Pulau Lemukutan, sedangkan 10 orang adalah tim pelaksana kegiatan bersama staf Desa Pulau Lemukutan. Kegiatan ini diikuti dengan penuh antusias oleh warga pesisir Pulau Lemukutan. Peserta yang dibagi menjadi 4 kelompok telah berhasil mempraktikkan materi yang disampaikan dan menghasilkan snack krenyes dan jelly boba dengan bentuk dan rasa yang menarik.

Kegiatan PKM ini terdiri atas beberapa tahapan, yaitu sebagai berikut.

1. Konsolidasi tim pelaksana, yaitu dosen Jurusan Ilmu Kelautan UNTAN bersama dengan mahasiswa yang diikutsertakan dalam kegiatan, pengurusan administrasi terkait perizinan dari kampus, dan perizinan dari desa tempat kegiatan yang dilakukan secara online.

2. Kegiatan ceramah materi dan demonstrasi/praktik membuat snack krenyes dan jelly boba dilakukan secara offline di Desa Pulau Lemukutan dengan menerapkan protokol kesehatan yang ketat kepada semua orang yang terlibat dalam kegiatan, baik sebagai panitia maupun peserta. Hal ini dilakukan dalam usaha memutus mata rantai penyebaran virus Covid-19, yaitu dengan tetap menggunakan masker dan mencuci tangan dengan sabun atau hand sanitizer serta menjaga jarak.

3. Persiapan alat dan bahan baku yang akan dibawa ke lokasi kegiatan seperti kompor, blender, panci, loyang, gula pasir, tepung gandung, tepung sagu, dan perlengkapan umum lainnya.

4. Kegiatan PKM ini dilaksanakan pada Minggu, 28 Maret 2021, dibagi menjadi dua acara, yaitu ceramah dengan materi terkait produksi cemilan rumput laut dan pemasarannya, kemudian dilanjutkan dengan acara praktik/demonstrasi pembuatan snack krenyes dan jelly boba dari rumput laut E. cottonii.

5. Peserta pelatihan sebanyak 40 orang dibagi menjadi 4 kelompok kegiatan dan mendapatkan sejumlah bahan yang sama untuk melakukan praktik pembuatan snack krenyes dan jelly boba. Kemampuan mengolah snack krenyes dan jelly boba dari rumput laut dinilai dari tekstur, penampilan, dan rasa dari produk akhir yang dihasilkan.

6. Seluruh produk yang dihasilkan selanjutnya dikemas dalam wadah, kemudian diberi label.

\section{Pelaksanaan Program}

Wilayah laut dan pesisir memiliki keanekaragaman sumber daya hayati yang berperan penting dalam aplikasi bioteknologi, obat-obatan, dan pangan (Larsen et al., 2011). Sektor perikanan dan budi daya merupakan sumber pangan yang besar dan dapat menghasilkan devisa bagi negara (Amosu et al., 2013). Usaha perikanan yang banyak dilakukan di pesisir Pulau Lemukutan adalah budi daya dengan komoditas rumput laut. Kegiatan ini memiliki potensi usaha yang besar sesuai dengan karakteristik wilayah di pulau tersebut. Budi daya rumput laut merupakan sektor yang potensial untuk dikembangkan di wilayah pesisir (Blankenhorn, 2007), termasuk di Pulau Lemukutan. Rumput laut memiliki kandungan nutrisi esensial, serat, dan protein tinggi (Murdinah, 
2011) yang dapat dimanfaatkan sebagai sumber pangan. Selain itu, olahan rumput laut juga memiliki nilai jual yang tinggi dan dapat meningkatkan perekonomian masyarakat.

Berdasarkan karakteristik lingkungan dan kondisi perairan, Pulau Lemukutan dapat dijadikan sebagai area budi daya rumput laut, khususnya spesies Eucheuma cottonii dan E. spinosum. Hal ini karena lokasi yang jauh dari pengaruh daratan dan kontur pulau dengan banyak teluk yang dapat melindungi komoditas budi daya dari arus dan gelombang yang kuat sehingga strategis untuk menjadi sentra budi daya rumput laut di Kalimantan Barat. Potensi sumber daya alam di Pulau Lemukutan menjadi sumber pendukung bagi majunya perekonomian di pulau tersebut. Sejak awal tahun 2011, Pulau Lemukutan telah menjadi sentra usaha budi daya rumput laut $E$. cottonii terbesar di Kalimantan Barat. Namun, keberhasilan usaha tidak diimbangi dengan kemampuan dan keterampilan masyarakat dalam membuat olahan rumput laut. Oleh karena itu, hasil panen rumput laut dijual dalam bentuk basah atau kering ke pengepul dari Kota Pontianak dan daerah lainnya.

Pandemi Covid-19 yang memberlakukan lock down atau pembatasan sosial berskala besar selama hampir sepanjang tahun 2020 telah menyerang semua sektor kehidupan. Menurunnya daya beli masyarakat secara global menyebabkan kemerosotan harga pada hampir semua komoditas pangan berbasis perikanan dan pertanian. Kondisi ini mengakibatkan pembudi daya mengalami kerugian dan usaha budi daya rumput laut di Pulau Lemukutan juga menurun. Di tingkat distributor, harga rumput laut menurun dari Rp12.500,00/kg bobot kering menjadi hanya Rp2.500,00/kg bobot kering. Nilai jual ini tidak dapat menutup biaya operasional selama kegiatan budi daya hingga pemanenan sehingga kondisi tersebut berpengaruh terhadap penurunan pendapatan keluarga masyarakat pesisir.

Hal inilah yang mendasari tim pelaksana PKM Jurusan Ilmu Kelautan Universitas Tanjungpura melaksanakan kegiatan PKM di Pulau Lemukutan sebagai salah satu bentuk kepedulian pada permasalahan yang dihadapi oleh masyarakat. Kegiatan PKM merupakan salah satu Tridharma Perguruan Tinggi, berusaha menggali permasalahan yang ada di masyarakat, kemudian secara bersama-sama memikirkan dan menerapkan solusi dari permasalahan tersebut. Selama ini, masyarakat Pulau Lemukutan telah melakukan kegiatan pengolahan rumput laut, tetapi masih sederhana berupa manisan, dodol, maupun sebagai campuran langsung dalam membuat puding dan pelengkap es cendol. Selain itu, pemasaran masih di tingkat lokal Pulau Lemukutan dan daratan sekitarnya dengan sistem produksi apabila ada pemesanan. Pada kegiatan PKM ini, kami memperkenalkan pembuatan snack krenyes dan jelly boba. Jenis makanan ini merupakan produk pangan olahan yang sedang digemari remaja saat ini, dengan bahan pembuatannya yang dapat dimodifikasi dari sumber karbohidrat seperti tepung sagu, gandum, dan rumput laut.

Kegiatan dimulai dengan ceramah tentang manfaat dari mengonsumsi rumput laut bagi kesehatan manusia. Rumput laut mengandung nutrisi esensial seperti zink, enzim, dan beberapa vitamin yang dapat dijadikan sebagai suplemen makanan (Dhargalkal and Pereira, 2005). Spesies E. Spinosum, khususnya, mengandung senyawa bioaktif yang dapat dimanfaatkan sebagai antioksidan (Sofiana et al., 2020). Mengonsumsi produk-produk perikanan seperti rumput laut dan ikan atau produk turunan dari komoditas tersebut pada ibu hamil dan menyusui serta anak balita dapat mencegah 

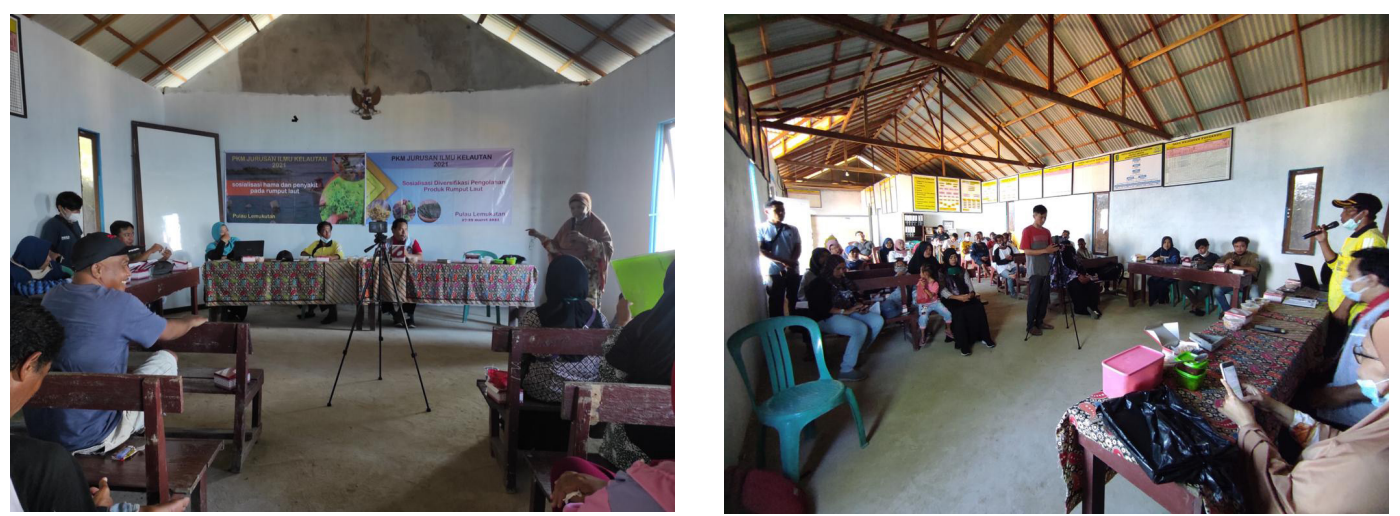

Gambar 1. Ceramah materi kegiatan

terjadinya stunting (Sofiana et al., 2021). Selain itu, konsumsi hasil laut dan olahannya seperti kerang, ikan, dan rumput laut juga dapat meningkatkan sistem imunitas tubuh sehingga tidak mudah terjangkit oleh virus (Warsidah et al., 2021), khususnya selama pandemi Covid-19.

Kegiatan ceramah berikutnya ialah tentang produksi olahan rumput laut dalam skala besar dan jangkauan pemasaran yang lebih luas. Menurunnya harga jual komoditas perikanan dan kelautan akibat pandemi Covid-19 menyebabkan penghasilan nelayan pembudi daya rumput laut juga menurun. Salah satu usaha untuk memberikan nilai tambah (added value) dan meningkatkan harga jual komoditas tersebut ialah dengan melakukan diversifikasi olahan. Aneka cemilan rumput laut saat ini menjadi produk yang sangat digemari, khususnya oleh para remaja sehingga dapat menjangkau pasar yang lebih luas. Kegiatan PKM dengan judul "Peningkatan Keterampilan dan Perekonomian Masyarakat Pesisir Pulau Lemukutan Kalimantan Barat melalui Pelatihan Pembuatan Snack berbasis Rumput Laut" diharapkan dapat meningkatkan keterampilan masyarakat dalam membuat olahan snack krenyes dan jelly boba.

\section{Pembuatan Snack Krenyes Rumput Laut}

Snack rumput laut krenyes dapat dibuat dengan berbagai cara, antara lain, yaitu dengan menghaluskannya terlebih dahulu, kemudian ditambahkan ke dalam adonan tepung dan bumbu pelengkap sebelum dikukus, diiris tipis, dan dikeringkan, kemudian digoreng. Selain itu, proses pengolahan dapat juga dilakukan tanpa menghaluskannya terlebih dahulu, tetapi langsung merendamnya dalam bumbu halus, kemudian digulingkan dalam telur dan tepung panir sebelum digoreng seperti yang dilakukan dalam kegiatan ini. Snack ini dibuat dengan cara membersihkan semua kotoran yang menempel pada rumput laut, kemudian merendamnya selama \pm 3 jam dalam air masak. Selanjutnya, rumput laut dipotong kecil-kecil sepanjang $2-3 \mathrm{~cm}$, lalu ditiriskan, kemudian direndam dalam larutan bumbu bawang putih, merica, lengkuas, kunyit, dan cabai rawit yang sudah dihaluskan bersama. Perendaman dilakukan selama 3 jam, kemudian dicelupkan ke dalam kocokan telur sebelum digulingkan lagi ke dalam tepung campuran gandum dan sagu untuk digoreng. Sebaiknya, penggorengan hasil akhir ini dilakukan dalam minyak panas dan suhunya diturunkan setelah 5 menit sampai penampakan snack 

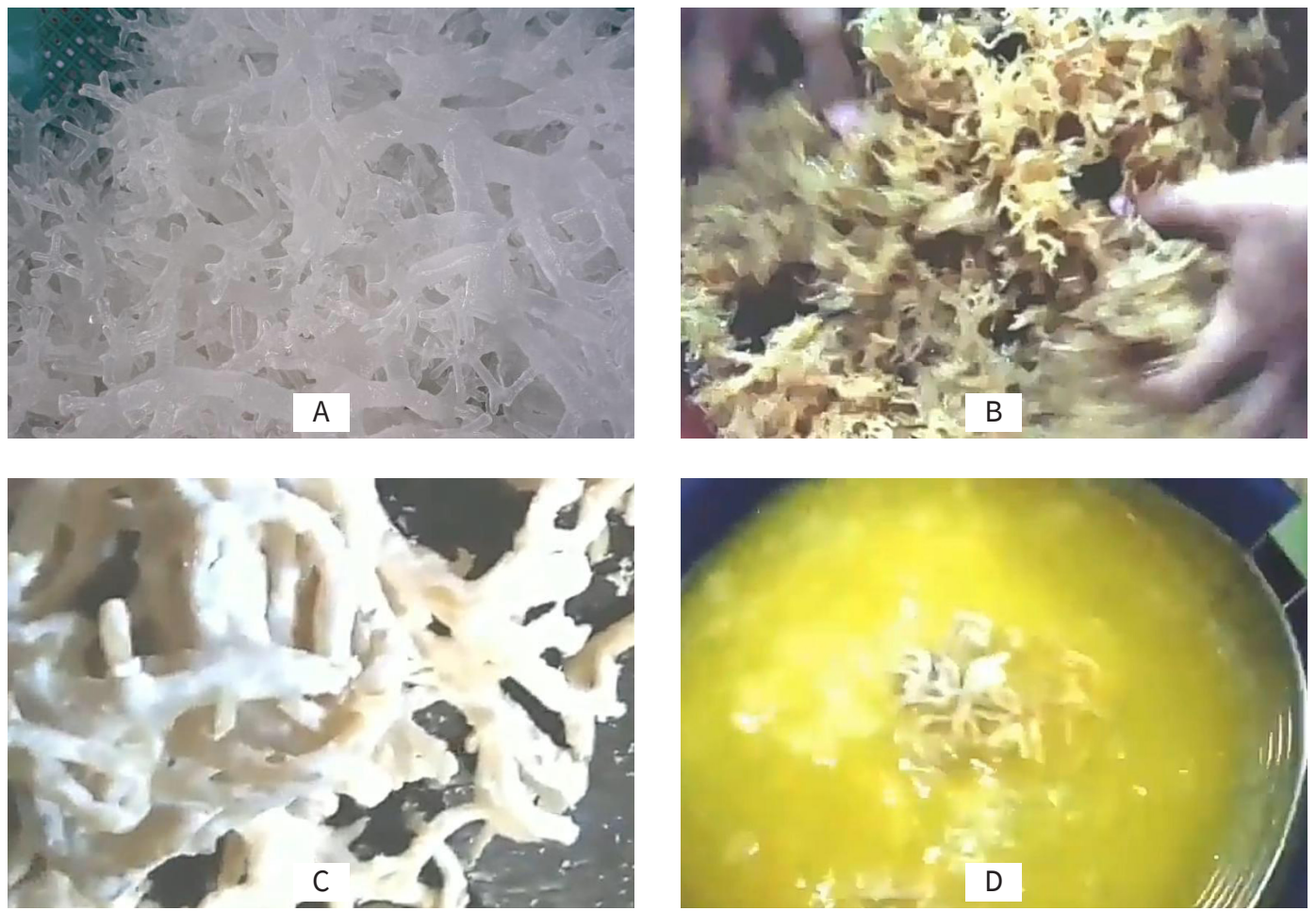

Gambar 2. Pembuatan snack krenyes rumput laut. (A) rumput laut hasil perendaman (B) diaduk dengan bumbu halus (C) digulingkan dalam tepung terigu dan sagu 1:1 (D) digoreng dalam minyak panas

krenyes ini berwarna kuning kecokelatan. Tidak perlu dilakukan penambahan bahan pengembang dan perenyah dalam adonan ini karena kandungan karagenan pada rumput laut sudah berfungsi sebagai perenyah pada snack tersebut.

\section{Pembuatan Jelly Boba Rumput Laut}

Produk olahan berikutnya adalah jelly boba. Olahan ini adalah bola tapioka dengan tekstur kenyal, berbentuk seperti mutiara yang ditambahkan ke dalam minuman utama seperti teh hitam, kopi es vanila, teh hijau, serta minuman lain yang beraroma dan rasa buah-buahan. Jelly boba dari rumput laut dibuat dengan menghaluskan rumput laut yang sudah dibersihkan dan sudah mengembang dalam air, kemudian dicampurkan dengan

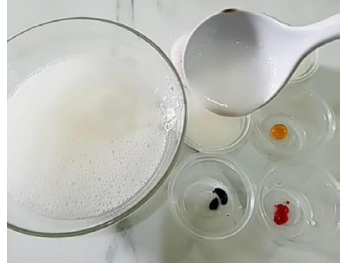

A

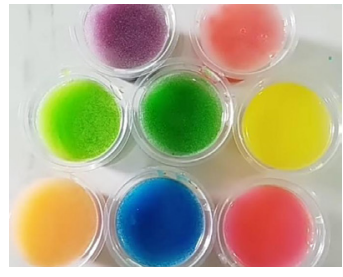

B

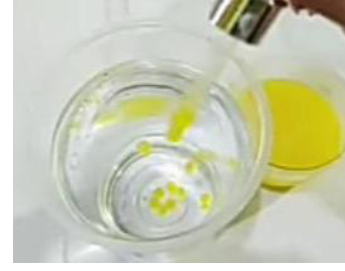

C

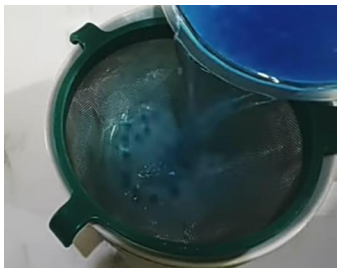

D

Gambar 3. Pembuatan jelly boba rumput laut. (A) rebusan rumput laut dan gula dimasukkan dalam wadah berisi pewarna makanan (B) rumput laut beku (C) membuat bola kecil ke dalam larutan kalsium laktat (D) menyaring bola jelly 
tepung tapioka dengan perbandingan 1: 2 (rumput laut: tepung tapioka), ditambahkan garam dan gula secukupnya, diadon sampai kalis dan dibentuk bulatan-bulatan kecil seukuran mutiara. Bulatan tersebut selanjutnya direbus dalam air mendidih sampai matang dan melayang di permukaan, kemudian ditiriskan, lalu didinginkan dan bisa segera dijadikan bahan tambahan ke dalam minuman utama.

\section{Refleksi Capaian Program}

Dua jenis olahan yang didemonstrasikan kepada masyarakat pesisir Pulau Lemukutan memiliki daya simpan yang lama, yakni antara $1-2$ minggu dalam penyimpanan dengan suhu kamar dan 5-6 minggu penyimpanan dengan suhu pendingin $4{ }^{\circ} \mathrm{C}$. Teknik pengemasan dilakukan dengan menggunakan vakum sehingga dapat menghindari kontaminasi udara ke dalam plastik. Hal ini menjadi keuntungan tersendiri bagi produsen karena pembuatan produk tidak harus menanti adanya pemesanan, tetapi bisa dipajang ke toko-toko yang menyediakan penyimpanan berpendingin. Seluruh peserta dalam kelompok produksi menunjukkan keterampilannya dalam mengolah rumput laut menjadi snack krenyes dengan indikator tekstur, bentuk, rasa, dan kerenyahan, serta jelly boba dengan indikator tekstur, bentuk, rasa, dan kekenyalan.

Tabel 1. Produk hasil keterampilan peserta pelatihan

\begin{tabular}{|c|c|c|c|c|c|c|c|c|}
\hline \multirow{2}{*}{$\begin{array}{c}\text { Kelom- } \\
\text { pok }\end{array}$} & \multicolumn{4}{|c|}{ Snack Krenyes } & \multicolumn{4}{c|}{ Jelly Boba } \\
\cline { 2 - 9 } & Tekstur & Bentuk & Rasa & Kerenyahan & Tekstur & Bentuk & Rasa & Kekenyalan \\
\hline 1 & Garing & $\begin{array}{c}\text { Kembang } \\
\text { kol mini }\end{array}$ & Gurih & Renyah & Halus & $\begin{array}{c}\text { Bulat } \\
\text { bola }\end{array}$ & Manis & Kenyal \\
\hline 2 & Garing & Merekah & Gurih & Renyah & Halus & Bulat & Tawar & Kenyal \\
\hline 3 & Garing & $\begin{array}{c}\text { Kembang } \\
\text { kol mini }\end{array}$ & Gurih & Renyah & Halus & Bulat & Manis & Agak keras \\
\hline 4 & $\begin{array}{c}\text { Agak } \\
\text { keras }\end{array}$ & $\begin{array}{c}\text { Kembang } \\
\text { kol mini }\end{array}$ & $\begin{array}{c}\text { Gurih } \\
\text { asin }\end{array}$ & Renyah & Halus & Bulat & Manis & Kenyal \\
\hline
\end{tabular}
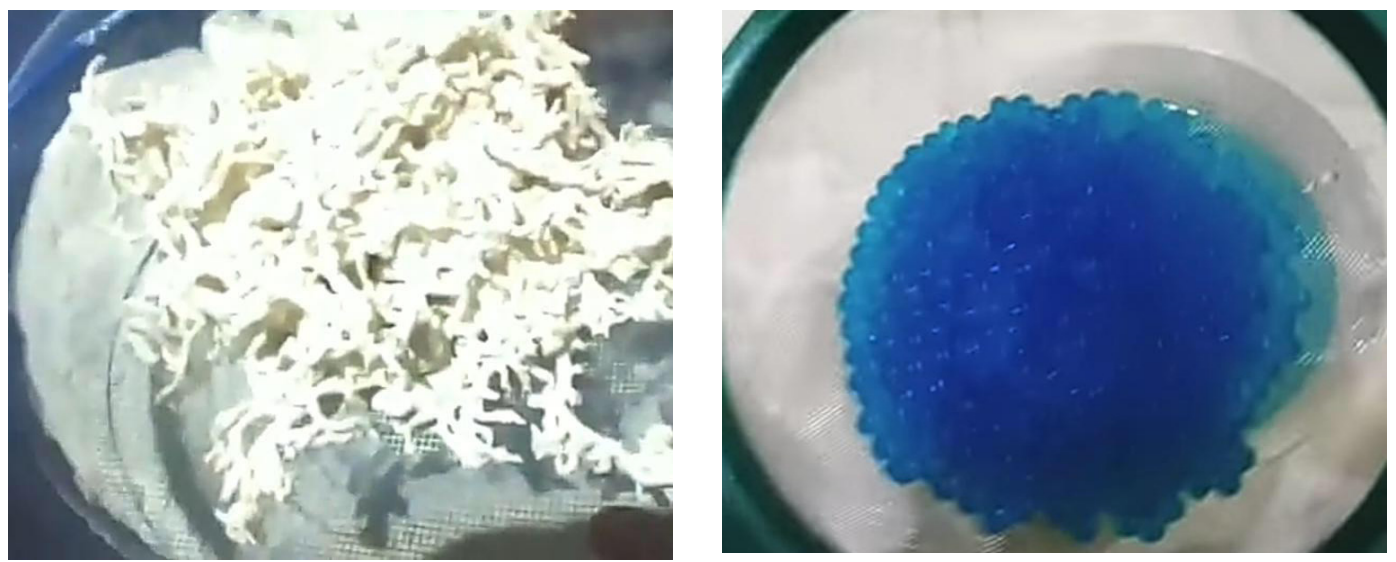

Gambar 4. Hasil produksi (kiri) snack krenyes dan (kanan) jelly boba 


\section{Penutup}

Dari hasil kegiatan PKM yang berjudul "Peningkatan Keterampilan dan Perekonomian Masyarakat Pesisir Pulau Lemukutan Kalimantan Barat melalui Pelatihan Pembuatan Snack berbasis Rumput Laut" dapat disimpulkan sebagai berikut.

1. Masyarakat peserta pelatihan telah dapat memproduksi snack krenyes dan jelly boba dari rumput laut dengan kualitas yang baik meliputi tekstur, penampilan, dan rasa, sampai pada pengemasan produk yang menarik.

2. Kegiatan pelatihan ini dapat menambah keterampilan masyarakat pesisir Pulau Lemukutan yang dapat meningkatkan harga jual komoditas rumput laut sehingga dapat mengembalikan aktivitas perekonomian di wilayah pesisir pulau tesebut.

3. Telah dihasilkan kader-kader desa yang mampu menyosialisasikan kegiatan ini kepada masyarakat yang ada di RT masing-masing.

\section{Ucapan Terima Kasih}

Terima kasih kepada Rektor Universitas Tanjungpura dan Dekanat Fakultas Matematika dan Ilmu Pengetahuan Alam atas Dana DIPA Fakultas yang digunakan dalam membiayai Kegiatan PKM ini.

\section{Daftar Pustaka}

Amosu, A.O.; Robertson-Andersson, D.V; Maneveldt, G.W.; Anderson, R.J.; Bolton, J.J. (2013). South African seaweed aquaculture: A sustainable development example for other African coastal Countries. African Journal of Agricultural Research, 8(43), 5268-5279, DOI: 10.5897/AJAR2013. 6994.

Badan Pusat Statistik Kabupaten Bengkayang. (2019). Kabupaten Bengkayang dalam Angka 2019. $336 \mathrm{hlm}$.

Blankenhorn, S.U. (2007). Seaweed Farming and Artisanal Fisheries in an Indonesian Seagrass bed-Complementary or Competitive Usages. [PhD thesis]: Faculty 2 Biology / Chemistry. University Bremen.

Dermawan, A.; Lubis, S.B.; Suraji. (2014). Status Pengelolaan Efektif Kawasan Konservasi Perairan, Pesisir dan Pulau-Pulau Kecil di Indonesia : Profil 113 Kawasan Konservasi Perairan, Pesisir dan Pulau-pulau Kecil Kalimantan, Direktorat Konservasi Kawasan dan Jenis Ikan dan Direktorat Jenderal Kelautan, Pesisir dan Pulau-pulau Kecil, Kementerian Kelautan Dan Perikanan.

Dhargalkal, V.K. and Pereira, N. (2005). Seaweed: Promising Plant of the Millenium. Science and Culture, 71(3), 60-6.

Hayashi, L.; Hurtado, A.Q.; Msuya, F.E.; Bleicher-Lhonneur, G.; and Critchley, A.T. (2010). A Review of Kappaphycus farm ᄀing: Prospects and Constraints, In Israel, A.; Einav, R.; and Seckbach, J. (Eds.) Seaweeds and Their Role in Globally Changing Environments: Cellular Origin, Life in Extreme Habitats and Astrobiology. Springer, New York, 251- 283.

Larsen, R.; Eilersten, K.E.; Elvevoll, E.O. (2011). Health Benefits of Marine Foods and Ingredients. Biotechnology Advaces, 29:, 508-518.

Pereira, R. and Yarish, C. (2008). Mass Production of Marine Macroalgae. In Jørgensen, 
S.E. and Fath, B.D. (Eds.) Encyclopedia of Ecology. Vol.3, Ecological Engineering, Elsevier, Oxford, 2236-2247.

Sofiana, M.S.J., Risko, Helena, S., Nurrahman, Y.A., Apriliani, Permana, G.I., Amelia, D.R., Pangestu, N.J., Septian, M.R., Meidiana, V., Adinur, R.S., Irawan, H., Lestari, R.D.A., Hidayat, M., Ramadhan, G., Tarigas, M.T. (2018). Keanekaragaman Makroalga di Perairan Pulau Lemukutan Kalimantan Barat. Mini Project Report. Marine Science Department, Faculty of Mathematics and Natural Sciences, Universitas Tanjungpura.

Sofiana, M.S.J.; Aritonang, A.B.; Safitri, I.; Helena, S.; Nurdiansyah, S.I.; Risko; Fadly, D.; Warsidah. (2020). Proximate, Phytochemicals, Total Phenolic Content and Antioxidant Activity of Ethanolic Extract of Eucheuma spinosum Seaweed. Sys Rev Pharm, 11(8), 228-232.

Sofiana, M.S.J.; Yuliono, A.; Warsidah, Safitri, I. (2021). Sosialisasi Pemanfaatan Pangan Hasil Laut dan Diversifikasi Olahannya Sebagai Usaha Menanggulangi Stunting Pada Anak Balita di Kalimantan Barat. Journal of Community Engagement in Health, 4(1), 103-112, https://doi.org/10.30994/jceh.v4i1.121.

Yuliono, A.; Warsidah; Sofiana, M.S.J.; Kushadiwijayanto, A.A.; Apriansyah; Nurrahman, Y.A.; Aritonang, A.B.. (2021). Sosialisasi Konsumsi Hasil Laut sebagai Pangan Fungsional dalam Usaha Peningkatan Sistem Imunitas Tubuh selama Masa Pandemi Covid-19 di Kota Pontianak, Kalimantan Barat. Community Engagement and Emergence Journal (CEEJ), 2(2), 183-193. https://doi.org/10.37385/ceej.v2i2.195. 